\title{
The effects of contextual group guided discovery learning on students' mathematical understanding and reasoning
}

\author{
Slamet Arifin ${ }^{1 *}$, Wahyudin Wahyudin ${ }^{2}$, Tatang Herman ${ }^{2}$ \\ ${ }^{1}$ Department of Elementary School Teacher Education, Universitas Kuningan. \\ Jalan Cut Nyak Dhien No. 36A Cijoho Kuningan 45512, Indonesia \\ ${ }^{2}$ Department of Mathematics Education, Universitas Pendidikan Indonesia \\ Jalan Dr. Setiabudhi No. 229 Bandung 40132, Indonesia \\ * Corresponding Author. E-mail: slamet.arifin@uniku.ac.id
}

Received: 7 July 2020; Revised: 12 July 2020; Accepted: 14 July 2020

\begin{abstract}
In this study, we examine the effect of contextual group guided discovery (CGGD) learning approach on students' mathematical understanding and reasoning. This study was conducted through a quasi-experimental method with a control group pre and post-test design. The participants of this study were two groups of $4^{\text {th }}$ grade students in Kuningan, Indonesia. Each group was comprised of 22 students $(\mathrm{N}=44)$. While the experimental group was conducting mathematics learning with the CGGD learning approach, the control group was conducting mathematics learning with problem-based learning (PBL). The data were collected through a test of students' mathematical understanding (TSMU) and a test of students' mathematical reasoning (TSMR) developed by researchers. The results showed that there were significant differences in the gain score of students' mathematical understanding (SMU) $(\mathrm{U}=134.00, \mathrm{Z}=-2.539, \mathrm{P}=0.011<0.05)$ and students' mathematical reasoning $(\mathrm{SMR})(\mathrm{U}=139.500, \mathrm{Z}=-2.412, \mathrm{P}=0.016<0.05)$ between the experimental and the control group. The gain score and post-test score of SMU and SMR on the experimental group that implemented the CGGD learning approach were significantly higher than the control group. Therefore, we conclude that the CGGD learning approach was proven influential to empower SMU and SMR.
\end{abstract}

Keywords: CGGD learning, mathematical understanding, mathematical reasoning.

How to Cite: Arifin, S., Wahyudin, W., \& Herman, T. (2020). The effects of contextual group guided discovery learning on students' mathematical understanding and reasoning. Jurnal Prima Edukasia, 8(2), 106-114. doi:https://doi.org/10.21831/jpe.v8i2.33059

\section{Introduction}

Mathematics has a fundamental role in the educational field to prepare the students to enable to overcome the challenges in this changing world. The National Council of Teacher Mathematics (NCTM) emphasize that in this changing world, those who understand and can do mathematics will have significantly enhanced opportunity and options for shaping the future (National Council of Teachers of Mathematics, 2000). In accordance with the current condition that the development of technology and digitalization have placed a special role of mathematics in science, technology, engineering and mathematics (STEM) in which most of the calculation learn by students from primary to high school level (Gravemeijer et al., 2017). Moreover, competence in mathematics not only determine success in this modern era but also affected to a better quality of life (Organisation for Economic Co-Operation and Development, 2015). Many studies have proved that mathematical ability has a positive correlation for students in many areas, particularly on STEM. For instance, Uhden et al. (2012) stated that mathematics and physic have deep interrelation. Therefore, following the essentials of mathematics in our daily and future life, mathematics learning should develop the students to be proficient in mathematics as they need to overcome the challenge in the future.

Our focus in this study highlighted the mathematical understanding and reasoning in mathematics teaching and learning. We use the terms of mathematical understanding that refers to conceptual understanding and procedural fluency. Conceptual understanding, procedural fluency, and adaptive reasoning are part of mathematical proficiency that should be developed when students are learning mathematics alongside strategic competence or problem-solving and productive disposition (Kilpatrick et al., 2001; 
National Council of Teachers of Mathematics, 2000). All the aspects of mathematics proficiency are connected and support each other in the processes of students' development of mathematical competence (Philipp \& Siegfried, 2015). Therefore, students need to learn mathematics with understanding and reasoning.

Mathematical understanding and reasoning have been focus and priority in the mathematics curriculum in many countries (Australian Curriculum Assessment and Reporting Authority, 2009; Kilpatrick et al., 2001; Menteri Pendidikan dan Kebudayaan Republik Indonesia, 2018; National Council of Teachers of Mathematics, 2000). For instance, National Council of Teachers of Mathematics (2000) emphasizes that students must learn mathematics with understanding, actively building new knowledge through experience, and prior knowledge. Mathematics aims to be relevant and applicable to $21^{\text {st }}$ century; therefore, proficiency of understanding, fluency, problem-solving, and reasoning emphasized in the curriculum to ensure students learning at the center of the curriculum (Australian Curriculum Assessment and Reporting Authority, 2018).

In this research, mathematical understanding is categorized into conceptual understanding and procedural fluency (Ben-Hur, 2006; Schneider et al., 2011). The conceptual understanding refers to an understanding of mathematical concepts, operation, and relations, procedural fluency is a skill in carrying out procedures flexibility, accurate, efficiently, and appropriately (Kilpatrick et al., 2001). Moreover, Conner et al. (2011) stated that conceptual understanding is the ability to understand mathematics concepts and know why it could be concluded. According to Fyfe et al. (2015) stated that when students learn a mathematics procedure or formula to solve a mathematical problem, it is not only simply encourage students to implement the procedure correctly, but also want them to understand why the procedure works.

Moreover, another aspect of mathematics proficiency that highlighted in this study was mathematical reasoning. The reasoning is generally regarded as a fundamental element in mathematics teaching and learning (National Council of Teachers of Mathematics, 2000). Reports from previous research proved that mathematical reasoning has an essential role in influencing students' mathematical problemsolving ability (Francisco \& Maher, 2005; Frosch \& Simms, 2015; Jäder et al., 2017). For instance, Johansson (2016) proved that mathematical reasoning required by students to get high achievement in mathematics tests. Reasoning requires conceptual underpinning, therefore mathematical activity such as applying rote procedures or providing memorized facts are not considered as reasoning (Melhuish et al., 2020). The mathematical reasoning process comprised of several activities such as specializing (making trials), determining patterns/relationship, conjecturing, generalizing, and convincing (Barnes, 2019). Therefore, mathematics learning should facilitate and support students in order to develop their mathematical understanding and reasoning.

However, there is an ongoing debate on the optimal way to learn mathematics. On one hand, there those who argue that students should learn mathematics guided by a teacher with a clear explanation of procedures followed by practice and correction (Baroody et al., 2015; Kirschner et al., 2006). Kirschner et al. (2006) proved that minimal guidance instruction was less effective than a learning approach that emphasizes on guidance for students during instruction. In the other hand of this debate are those who argue that mathematics learning is best when students understand mathematics concepts trough solving mathematics task for themselves when they have opportunity to make investigation, justification, and link different mathematics concepts (Schwartz \& Martin, 2004; Sullivan et al., 2020).

Therefore, in this study, we investigated the effect of the implementation of contextual group guided discovery learning (CGGD) based sociocultural as a learning approach that was designed by the researchers compared with problem-based learning (PBL) on students mathematical understanding and reasoning in the mathematics topics of length and area of the square, rectangle, and triangle. The CGGD learning approach was developed based on the principles of sociocultural theory as an alternative approach in mathematics teaching and learning. Social-constructivist theory emphasizes that learning resulted from an interaction between people and with material and representational tools offered by the learning environment (Goos, 2010). Meaningful student understanding is more likely to occur in classrooms in which the students and the teacher mutually share mathematical authority (Ellis et al., 2019). The CGGD learning approach was developed by the combination of the principles of contextual teaching, collaborative learning, and guided discovery learning. Learning mathematics in a contextual setting is very important for the student to link their experience and mathematics content. Lam (2007) concluded 
that through contextual approach could strengthen previous students' mathematical understanding and improve students' ability to learn new mathematical concepts through solving real problems.

Moreover, in particular, the following research questions were explored in our study:

RQ 1. Does any differences of SMU between students who learn mathematics with CGGD and PBL learning approach?

RQ 2. Does any differences of SMR between students who learn mathematics with CGGD and PBL learning approach?

\section{Method}

\section{Research Design}

This research was conducted in a quasi-experimental with control group pre-test and post-test design. This design involved students divided into experimental and control groups, with each group was given a different treatment. In particular, the research design presented in Table 1.

Tabel 1. Quasi-experimental control group design

\begin{tabular}{cccc}
\hline Groups & Pre-test & Treatment & Post-test \\
\hline Experimental & $\mathrm{O}_{1}$ & $C G G D$ & $\mathrm{O}_{2}$ \\
Control & $\mathrm{O}_{1}$ & $P B L$ & $\mathrm{O}_{2}$ \\
\hline
\end{tabular}

There were different treatments of learning approaches implemented in the experimental and control groups. While the CGGD learning approach was conducted as the treatment in the experimental group, the problem-based learning (PBL) approach was implemented in the control group. The treatment in each group was conducted three times a series of mathematics lessons, 3 x 150 minutes. Before and after treatment, the pre-test and post-test of students' mathematical understanding and reasoning were administered to the students.

\section{Participants}

Two classes of 44 fourth grade students (9 to 10 years old), who were learning length and area of the square, rectangle, and triangle in the school participated in this quasi-experimental study. The two classes of the participants were located from similar elementary school in Kuningan, Indonesia.

Intervention

The instructional design in the experimental group was delivered by the first author while the students in the control group delivered by the teacher. The experimental group was conducting mathematics learning through CGGD learning approach, and the control group was conducting mathematics learning through PBL learning approach. The treatment in each group was conducted in three timesseries of a mathematics lesson, $3 \times 150$ minutes. The lesson plan was developed to deliver mathematics learning on the topic of the length and area or square, rectangle, and triangle.

Data collection

Table 2. The criteria of SMU measurement

\begin{tabular}{cl}
\hline $\begin{array}{c}\text { Types of } \\
\text { Understanding }\end{array}$ & \multicolumn{1}{c}{ Indicators } \\
\hline $\begin{array}{c}\text { Conceptual } \\
\text { Understanding }\end{array}$ & $\begin{array}{l}\text { 1. The ability to connect among mathematical concepts and idea } \\
\text { 2. The ability to represent a mathematical situation in a different way. } \\
\text { 3. The students ability to use mathematical representation to solve specific } \\
\text { mathematics problems. }\end{array}$ \\
\hline Procedural Fluency & $\begin{array}{l}\text { 1. The ability to use mathematical procedures or formula accurately } \\
\text { 2. The ability to implement a mathematical procedure to solve mathematics } \\
\text { problems in a different situation. }\end{array}$ \\
& $\begin{array}{l}\text { 3. The students ability to modify mathematics procedures to solve a mathematics } \\
\text { problem. }\end{array}$
\end{tabular}

In this study, the data were collected through a test of students' mathematical reasoning (TSMU) and a test of students' mathematical reasoning (TSMR) developed by the researchers. The TSMU and TSMR were administered to 22 fourth-grade students in the experimental group and 22 of fourth-grade 
students in the control group. The test was administered before (pre-test) and after (post-test) the treatment in each group was implemented. The TSMU comprised of 6 mathematical problems that were developed to assess students mathematical understanding (SMU) related to the topic of length and area of square, rectangle, and triangle. The TSMU was developed based on the criteria of SMU measurement, as presented in Table 2 .

Moreover, the TSMR comprised of seven mathematical problems that were developed to assess students' mathematical reasoning (SMR) ability related to the topic of length and area measurement of the square, rectangle, and triangle. The TSMR was developed following the criteria of SMR measurement, as presented in Table 3 .

Table 3. The criteria of SMR measurement

\begin{tabular}{cl}
\hline Test of Reasoning & \multicolumn{1}{c}{ Indicator of Mathematical Reasoning } \\
\hline $\begin{array}{c}\text { Mathematical } \\
\text { Reasoning }\end{array}$ & $\begin{array}{l}\text { 1. Determining, explaining, or implementing the number connections, expression, } \\
\text { quantity and form to solve mathematics problems. }\end{array}$ \\
& $\begin{array}{l}\text { 2. Connecting mathematical knowledge, representation, and procedures to solve } \\
\text { mathematics problems. }\end{array}$ \\
& $\begin{array}{l}\text { 3. Making a justification for solving mathematics problems that never found before. } \\
\text { 4. Making a valid conclusion based on the information and evidence. }\end{array}$ \\
\hline
\end{tabular}

Data Analysis

Statistical analysis of the quantitative data was conducted using the Mann-Whitney test. The prerequisite tests consist of normality, homogeneity, and balance tests that were conducted before the Mann-Whitney test. The normality test was conducted to determine whether the sample under study is normally distributed or not. The normality test in this research used the Kolmogorov Smirnov. The homogeneity test was conducted to determine whether several populations variants are the same or not. All the statistical test were conducted through a statistic software program named IBM SPSS 22.

\section{Result and Discussion}

Result

\section{Descriptive statistic result}

The first phase of the data analysis process was conducted using the descriptive analysis to drawn the data collected from the pre-test and post-test of SMU and SMR. Hence, The descriptive statistic result of pre-test and post-test of SMU and SMR are presented in Table 4.

Table 4. Descriptive statistic of pre and post-test of SMU

\begin{tabular}{|c|c|c|c|c|}
\hline \multirow{2}{*}{ Groups } & \multirow{2}{*}{ Statistic } & \multicolumn{2}{|c|}{ Score } & \multirow{2}{*}{$\mathrm{N}$} \\
\hline & & Pre-Test & Post-test & \\
\hline \multirow{4}{*}{ PBL } & Mean & 34.318 & 62.954 & \multirow{4}{*}{22} \\
\hline & Std. Deviation & 12.276 & 16.158 & \\
\hline & Minimum & 10.00 & 40 & \\
\hline & Maximum & 55.00 & 100 & \\
\hline \multirow{4}{*}{ CGGD } & Mean & 37.727 & 68.227 & \multirow{4}{*}{22} \\
\hline & Std. Deviation & 11.518 & 17.824 & \\
\hline & Minimum & 20.00 & 25 & \\
\hline & Maximum & 60.00 & 100 & \\
\hline
\end{tabular}

The data presented in Table 4 shows that the descriptive statistic score of the pre-test of SMU on the control group that conducting learning through PBL $(M=34.318, \mathrm{SD}=12.276$, Min $=10.00, \mathrm{Max}=$ 55.00). Following this result, the post-test of SMU on the control group students shows $(M=62.954$, $\mathrm{SD}=16.158, \mathrm{Min}=40.00, \mathrm{Max}=100.00$ ). In the other hand, according to the data presented in Table 3, the experimental group students who were conducting learning through CGGD show that the pre-test score of SMU $(M=37.727, \mathrm{SD}=11.518$, Min=20.00, Max=60.00). Moreover, the port-test score shows $(M=68.227, \mathrm{SD}=17.824, \mathrm{Min}=25, \mathrm{Max}=100)$. Following the result of descriptive statistic test of the pretest and post score of SMU, the descriptive statistic test was also conducted to analyze the data of pretest and post-test of SMR. For more detail, the result of descriptive statistic test of pre and post-test of SMR are presented in Table 5. 
Jurnal Prima Edukasia, 8 (2), 2020 - 110

Slamet Arifin, Wahyudin Wahyudin, Tatang Herman

Table 5. Descriptive statistic of pre and post-test of SMR

\begin{tabular}{|c|c|c|c|c|}
\hline \multirow{2}{*}{ Groups } & \multirow{2}{*}{ Statistic } & \multicolumn{2}{|c|}{ Score } & \multirow[t]{2}{*}{$\mathrm{N}$} \\
\hline & & Pre-Test & Post-test & \\
\hline \multirow[t]{4}{*}{ PBL } & Mean & 32.181 & 61.272 & \\
\hline & Std. Deviation & 9.902 & 20.100 & 22 \\
\hline & Minimum & 14.00 & 21.00 & \\
\hline & Maximum & 50.00 & 100.00 & \\
\hline \multirow[t]{4}{*}{ CGGD } & Mean & 31.863 & 72.954 & \\
\hline & Std. Deviation & 8.929 & 19.924 & 22 \\
\hline & Minimum & 14.00 & 21.00 & \\
\hline & Maximum & 50.00 & 100.00 & \\
\hline
\end{tabular}

According to the data presented in Table 5, the descriptive statistic score of pre-test of SMR on the control group that conducting learning through PBL $($ Mean $=32.181, \mathrm{SD}=9.902$, $\mathrm{Min}=14.00$, Max $=50.00)$, and the post-test of SMR shows $(M=61.272, \mathrm{SD}=20.100, \operatorname{Min}=21.00, \operatorname{Max}=100.00)$. Furthermore, according to the data presented in Table 4, the experimental group students who were conducting learning through CGGD show that the pre-test score of SMR $(M=31.363, \mathrm{SD}=8.929$, Min=14.00, Max=50.00), and the post-test score of SMR shows $(M=72.954, \mathrm{SD}=19.924, \mathrm{Min}=21.00$, Max=100.00). Moreover, in order to examine the differences in the effectivity of each learning approach to the students' improvement in SMU and SMR, we use the gain score. The detailed analysis result of the gains score of SMU and SMR are presented in Table 6.

Table 6. Descriptive statistic of Gain Score of SMU and SMR

\begin{tabular}{llccc}
\hline \multirow{2}{*}{ Groups } & \multicolumn{1}{c}{ Statistic } & \multicolumn{2}{c}{ Gain Score } & \multirow{2}{*}{ N } \\
\cline { 3 - 4 } PBL & Mean & 41.054 & SMR & \\
& Std. Deviation & 21.690 & 20.472 & \\
& Minimum & 6.25 & 8.796 & 22 \\
\multirow{4}{*}{ CGGD } & Maximum & 100.00 & 100.00 & \\
& Mean & 54.895 & 62.462 & \\
& Std. Deviation & 22.100 & 25.031 & \multirow{2}{*}{22} \\
& Minimum & .00 & 8.14 & \\
& Maximum & 100.00 & 100.00 & \\
\hline
\end{tabular}

Table 6 shows that the gain score of the SMU test of the students who were learning through PBL $(M=41.054, \mathrm{SD}=21.690$, Min. 6.25, Max=100.00), and the students with CGGD learning model shows $(M=54.894, \mathrm{SD}=21.100$, Min=0.00, Max=100.00). Moreover, for the gain score of the SMR, the students with PBL shows $(M=45.472, \mathrm{SD}=20.796$, Min=8.14, Max=100.00), following this result, students with CGGD learning model shows $(M=62.465, \mathrm{SD}=25.031$, Min=8.14, $\mathrm{Max}=100.00)$.

Normality and Homogeneity Test

The normality and homogeneity test was conducted as a prerequisite test to determine whether the hypothetical test conducted through the parametric or non-parametric test. The normality test of the gain score of SMU and SMR are presented in Table 7.

Table 7. The Normality Test of Gain Score of SMU and SMR

\begin{tabular}{llccc}
\hline \multirow{2}{*}{ Variable } & \multirow{2}{*}{ Groups } & \multicolumn{3}{c}{ Kolmogorov-Smirnov $^{\mathrm{a}}$} \\
\cline { 3 - 5 } & PBL & Statistic & Df & Sig. \\
\hline SMU & CGGD & .204 & 22 & .018 \\
& PBL & .161 & 22 & .144 \\
& CGGD & .196 & 22 & .028 \\
& .150 & 22 & $.200^{*}$ \\
\hline
\end{tabular}

*. This is a lower bound of the true significance

a. Lilliefors Significance Correction

According to the normality test result of the gains score of SMU and SMR that shown in Table 7, the normality test for SMU of students with PBL indicates that $(\mathrm{D}(22=0.018, \mathrm{P}<0.05)$, therefore it can be concluded that the SMU score of students with PBL is not normally distributed. On the other hand, the gain score of the SMU test of students with CGGD shows that $(\mathrm{D}(22)=0.144, \mathrm{p}>0.05)$. 
Following this result, it can be concluded that the gains score of SMU of students with CGGD is normally distributed. Furthermore, the normality test of the gain score of SMR for the students with PBL shows $(\mathrm{D}(22=0.028, \mathrm{P}<0.05)$. Therefore, according to those results, it can be concluded that the gains score of SMR is not normally distributed. Moreover, the normality test of gains score of SMR students with CGGD shows $(\mathrm{D}(22=0.200, \mathrm{P}>0.05)$, based on this result, it can be concluded that the data are normally distributed.

After the prerequisite test conducted through the normality test, then the homogeneity test of variance was conducted to determine whether the data were homogenous or heterogenous. The result of the homogeneity test is presented in Table 8 .

Table 8. The homogeneity test of the gain score of SMU and SMR

\begin{tabular}{ccccc}
\hline Variable & Levene Statistic & df1 & df2 & Sig. \\
\hline SMU & .017 & 1 & 42 & .897 \\
SMR & .079 & 1 & 42 & .780 \\
\hline
\end{tabular}

As the data presented in Table 8, the gains score of SMU test shows $(P=0.897,>0.05)$, and the gain score of SMR test indicates $(\mathrm{P}=0.780,>0.05)$. Therefore, the result of the homogeneity test presented in Table 8 indicates that both the gain score of SMU and SMR is homogeny. Even though the homogeneity test of variance shows that the data are homogeny, but the normality test of data shows that the gain score of SMU and SMR test of students with PBL is not normally distributed. Following this result, the hypothetical test was conducted through a non-parametric test using the Mann-Whitney test.

\section{Mann-Whitney Test}

The Mann-Whitney test was conducted to test the hypothesis. The result of the hypothetical test is presented in Table 8 .

Table 8. Mann-Whitney test of SMU and SMR

\begin{tabular}{|c|c|c|}
\hline Variable & Statistic & Score \\
\hline \multirow[t]{4}{*}{ SMU } & Mann-Whitney U & 134.00 \\
\hline & Wilcoxon & 387.000 \\
\hline & $\mathrm{Z}$ & -2.539 \\
\hline & Asymp. Sig. (2-tailed) & 0.011 \\
\hline \multirow[t]{4}{*}{ SMR } & Mann-Whitney U & 139.500 \\
\hline & Wilcoxon & 392.500 \\
\hline & $\mathrm{Z}$ & -2.412 \\
\hline & Asymp. Sig. (2-tailed) & 0.016 \\
\hline
\end{tabular}

From the data presented in Table 8, it can be concluded that the SMU test score in the experimental group that was implementing CGGD learning was significantly different from the control group that was conducting mathematics learning through PBL, $(\mathrm{U}=134.00, \mathrm{Z}=-2.539, \mathrm{P}=0.011<$ $0.05)$. Moreover, the SMR test score for students who were conducting mathematics leaning through CGGD learning was significantly different from the students with PBL $(\mathrm{U}=139.500, \mathrm{Z}=-2.412, \mathrm{P}=$ $0.016<0.05)$. Therefore, it can be concluded that the CGGD learning approach was more effective than the PBL in improving SMU and SMR on the topic of length and area measurement of the square, rectangle, and triangle.

Discussion

The purpose of this study was to examine the effectiveness of CGGD learning approach toward SMU and SMR. Our research findings show that there were significant differences in the SMU and SMR between the students who learned the mathematics topic of length and area measurement of the square, rectangle, and triangle through the CGGD leaning approach and the students who learned with PBL learning approach. This finding in accordance with the previous research that proved learning approach that has minimal guidance less effective than those with guidance (Kirschner et al., 2006; Steinthorsdottir \& Sriraman, 2009; Baroody et al., 2015). The CGGD learning model is a learning model that emphasizes the role of the teacher in the process of thinking or discovering mathematical concepts that are compared to PBL learning models that previous research categorized as a learning model with 
minimum guidance (Kirschner et al., 2006). The findings in this study were proved that teacher guidance is important in supporting students' process of understanding mathematical concepts. In accordance with this finding, Steinthorsdottir and Sriraman (2009) proved that teacher has an important role that affected students reasoning. Alfieri et al. (2011) proved that guided discovery learning is more effective compared to other learning in terms of encouraging students to learn new material. In line with these findings, Loibl and Rummel (2014) proved that guidance (guidance) helps students to find better problem-solving solutions. Therefore, it is important for the teacher to provide guidance for the students to develop their mathematical understanding and reasoning.

The findings in this study are also supported by sociocultural theory, wherein the process of reaching the zone of proximal development (ZPD), students need guidance from others who more competent in order to achieve their ZPD (Ormrod, 2016; Schunk, 2012). On the other hand, in particular, students who learn through the PBL learning model or the minimum guidance learning model, in general, are less guidance. The CGGD learning model provides more opportunities for students to carry out social interactions with teachers who are equipped with assistance to exchange discussions in building relationships. Students involvement with others provide an opportunity for them to evaluate and adjust their understanding as a result of exploration with others' views and their participation (Gauvain et al., 2011). This is in accordance with Gillies and Haynes (2011) proved that students who learn with cooperative and strategic questioning conditions are more involved in elaboration activity and perform higher scores than students who only learn with the cooperative. Group work and communication can improve students' critical thinking and problem-solving skills (Koçak et al., 2009).

Moreover, communication with the teacher is essential for students to develop their understanding and reasoning. Previous research conducted by Fyfe and Brown (2018) proved that teacher feedback had a positive effect on low-knowledge learners toward the procedural and conceptual outcome. Furthermore, according to Liu et al. (2018) proved that teacher support significantly had a direct influence on academic self-efficacy and enjoyment in learning mathematics. Therefore, teacher role is important to support students' success in mathematics learning.

\section{Conclusion}

According to the findings and the discussion mentioned earlier, there some conclusions related to this study. The CGGD learning model was proved that have a significant effect on the SMU and SMR. The CGGD learning approach was influential in developing SMU and SMR. Therefore, the CGGD learning model is decent to implement by mathematics educators as an alternative learning model in teaching mathematics. Moreover, our finding proved that students who learned under the guidance of the teacher performed better achievement on their SMU and SMR than students who learn with minimum guidance by the teacher. Therefore, it is important for mathematics educators to give certain guidance in certain circumstances to support students learning mathematics with understanding.

\section{References}

Alfieri, L., Brooks, P. J., Aldrich, N. J., \& Tenenbaum, H. R. (2011). Does discovery-based instruction enhance learning? Journal of Educational Psychology, 103(1), 1-18. https://doi.org/10.1037/a0021017

Australian Curriculum Assessment and Reporting Authority. (2009). Shape of the Australian Curriculum: Mathematics. National Curriculum Board.

Australian Curriculum Assessment and Reporting Authority. (2018). Mathematics proficiencies. Australian Curriculum, Assessment and Reporting Authority (ACARA). https://www.australiancurriculum.edu.au/resources/mathematics-proficiencies/

Barnes, A. (2019). Perseverance in mathematical reasoning: the role of children's conative focus in the productive interplay between cognition and affect. Research in Mathematics Education, 21(3), 271-294. https://doi.org/10.1080/14794802.2019.1590229

Baroody, A. J., Purpura, D. J., Eiland, M. D., \& Reid, E. E. (2015). The impact of highly and minimally guided discovery instruction on promoting the learning of reasoning strategies for basic add- 1 and doubles combinations. Early Childhood Research Quarterly, 30(PA), 93-105. https://doi.org/10.1016/j.ecresq.2014.09.003 
Ben-Hur, M. (2006). Concept-rich mathematics instruction: Building a strong foundation for reasoning and problem solving. ASCD.

Conner, A. M., Wilson, P. S., \& Kim, H. J. (2011). Building on mathematical events in the classroom. ZDM - International Journal on Mathematics Education, 43(6), 979-992. https://doi.org/10.1007/s11858-011-0362-1

Ellis, A., Özgür, Z., \& Reiten, L. (2019). Teacher moves for supporting student reasoning. Mathematics Education Research Journal, 31(2), 107-132. https://doi.org/10.1007/s13394-018-0246-6

Francisco, J. M., \& Maher, C. A. (2005). Conditions for promoting reasoning in problem solving: Insights from a longitudinal study. Journal of Mathematical Behavior, 24(3-4), 361-372. https://doi.org/10.1016/j.jmathb.2005.09.001

Frosch, C., \& Simms, V. (2015). Understanding the role of reasoning ability in mathematical achievement. Euro Asian Pacific Joint Conference on Cognitive Science. https://doi.org/10.13140/RG.2.1.1107.2727

Fyfe, E. R., \& Brown, S. A. (2018). Feedback influences children's reasoning about math equivalence: A meta-analytic review. Thinking and Reasoning, 24(2), 157-178. https://doi.org/10.1080/13546783.2017.1359208

Fyfe, E. R., Mcneil, N. M., \& Borjas, S. (2015). Benefits of “concreteness fading” for children's mathematics understanding. Learning and Instruction, 35, 104-120. https://doi.org/10.1016/j.learninstruc.2014.10.004

Gauvain, M., Beebe, H., \& Zhao, S. (2011). Applying the cultural approach to cognitive development. Journal of Cognition and Development, 12(2), 121-133. https://doi.org/10.1080/15248372.2011.563481

Gillies, R. M., \& Haynes, M. (2011). Increasing explanatory behaviour, problem-solving, and reasoning within classes using cooperative group work. Instructional Science, 39(3), 349-366. https://doi.org/10.1007/s11251-010-9130-9

Goos, M. (2010). A sociocultural framework for understanding technology integration in secondary school mathematics. PNA, 5(1), 173-182.

Gravemeijer, K., Stephan, M., Julie, C., Lin, F.-L., \& Ohtani, M. (2017). What mathematics education may prepare students for the society of the future? International Journal of Science and Mathematics Education, 15(S1), 105-123. https://doi.org/10.1007/s10763-017-9814-6

Jäder, J., Sidenvall, J., \& Sumpter, L. (2017). Students' mathematical reasoning and beliefs in nonroutine task solving. International Journal of Science and Mathematics Education, 15(4), 759776. https://doi.org/10.1007/s10763-016-9712-3

Johansson, H. (2016). Mathematical reasoning requirements in Swedish national physics tests. International Journal of Science and Mathematics Education, 14(6), 1133-1152. https://doi.org/10.1007/s10763-015-9636-3

Kilpatrick, J., Swafford, J., \& Findell, B. (2001). Adding it up. National Academy Press.

Kirschner, P. A., Sweller, J., \& Clark, R. E. (2006). Why minimal guidance during instruction does not work: An analysis of the failure of constructivist, discovery, problem-based, experiential, and $\begin{array}{llll}\text { inquiry-based teaching. } \quad \text { Educational } & \text { Psychologist, }\end{array}$ https://doi.org/10.1207/s15326985ep4102_1

Koçak, Z. F., Bozan, R., \& Işı, Ö. (2009). The importance of group work in mathematics. Procedia Social and Behavioral Sciences, 1(1), 2363-2365. https://doi.org/10.1016/j.sbspro.2009.01.414

Lam, T. T. (2007). Contextual approach in teaching mathematics: an example using the sum of series of positive integers. International Journal of Mathematical Education in Science and Technology, 38(2), 273-282. https://doi.org/10.1080/00207390600913376

Liu, R.-D., Zhen, R., Ding, Y., Liu, Y., Wang, J., Jiang, R., \& Xu, L. (2018). Teacher support and math engagement: roles of academic self-efficacy and positive emotions. Educational Psychology, 38(1), 3-16. https://doi.org/10.1080/01443410.2017.1359238

Loibl, K., \& Rummel, N. (2014). The impact of guidance during problem-solving prior to instruction on students' inventions and learning outcomes. Instructional Science, 42(3), 305-326. 
Jurnal Prima Edukasia, 8 (2), 2020 - 114

Slamet Arifin, Wahyudin Wahyudin, Tatang Herman

https://doi.org/10.1007/s11251-013-9282-5

Melhuish, K., Thanheiser, E., \& Guyot, L. (2020). Elementary school teachers' noticing of essential mathematical reasoning forms: justification and generalization. Journal of Mathematics Teacher Education, 23(1), 35-67. https://doi.org/10.1007/s10857-018-9408-4

Menteri Pendidikan dan Kebudayaan Republik Indonesia. (2018). Peraturan Menteri Pendidikan dan Kebudayaan Republik Indonesia Nomor 37 tahun 2018 Tentang Perubahan Atas Peraturan Menteri Pendidikan dan Kebudayaan Nomor 24 Tahun 2016 tentang Kompetensi Inti dan Kompetensi Dasar Pelajaran pada Kurikulum 2013 pada Pendi (No. 37).

National Council of Teachers of Mathematics. (2000). Principles and standards for school mathematics. National Council of Teachers of Mathematics.

Organisation for Economic Co-Operation and Development. (2015). Pisa 2015 results in focus.

Ormrod, J. E. (2016). Human learning (7th Editio). Pearson Education, Inc.

Philipp, R. A., \& Siegfried, J. M. (2015). Studying productive disposition: the early development of a construct. Journal of Mathematics Teacher Education, 18(5), 489-499. https://doi.org/10.1007/s10857-015-9317-8

Schneider, M., Rittle-Johnson, B., \& Star, J. R. (2011). Relations among conceptual knowledge, procedural knowledge, and procedural flexibility in two samples differing in prior knowledge. Developmental Psychology, 47(6), 1525-1538. https://doi.org/10.1037/a0024997

Schunk, D. H. (2012). Learning theories. Printice Hall Inc.

Schwartz, D. L., \& Martin, T. (2004). Inventing to prepare for future learning: The hidden efficiency of encouraging original student production in statistics instruction. Cognition and Instruction, 22(2), 129-184. https://doi.org/10.1207/s1532690xci2202_1

Steinthorsdottir, O. B., \& Sriraman, B. (2009). Icelandic 5th-grade girls' developmental trajectories in proportional reasoning. Mathematics Education Research Journal, 21(1), 6-30. https://doi.org/10.1007/BF03217536

Sullivan, P., Bobis, J., Downton, A., Feng, M., Hughes, S., Livy, S., McCormick, M., \& Russo, J. (2020). Threats and opportunities in remote learning of mathematics: implication for the return to the classroom. Mathematics Education Research Journal, Lp 180100611. https://doi.org/10.1007/s13394-020-00339-6

Uhden, O., Karam, R., Pietrocola, M., \& Pospiech, G. (2012). Modelling mathematical reasoning in physics education. Science \& Education, 21(4), 485-506. https://doi.org/10.1007/s11191-0119396-6 